\title{
Lipid Metabolism in the Newborn Heart*
}

\author{
Benjamin Wittels † and Rubin Bressler \\ (From the Departments of Pathology and Medicine, Duke University Medical Center,
} Durham, N.C.)

In recent years long chain fatty acids have been shown to be the principal metabolic fuel of the adult heart (1-3). For the tissues of the mammalian fetus, however, carbohydrates rather than lipids appear to serve as the primary source of energy $(4,5)$. This difference in energy metabolism related to maturation suggested that the heart of the newborn, in contrast to that of the adult, might be unable to utilize long chain fatty acids and perforce must rely on glucose as the major substrate for energy production.

After the observation that the rate of long chain fatty acid oxidation in tissues was enhanced by carnitine ( $\gamma$-trimethyl ammonium $\beta$-hydroxybutyrate) (6), intensive investigation was undertaken to elucidate the mechanism of action of this compound. Carnitine, a normal constituent of many tissues, is especially abundant in myocardium $(7,8)$. From the evidence obtained in several laboratories $(9,10)$, it has been proposed that carnitine effects a stimulation of long chain fatty acid oxidation by functioning as a carrier of activated long chain fatty acyl groups from the extramitochondrial cytoplasm to the intramitochondrial sites of fatty acid oxidation. In this operation, a reversible transesterification between long chain fatty acyl CoA and carnitine has been demonstrated whereby long chain fatty acylcarnitine is formed. As acylcarnitine esters, the long chain fatty acids can be translocated across the mitochondrial membrane, which is relatively impermeable to acyl CoA molecules. The transesterification reaction is catalyzed by a long chain fatty acyl CoA-carnitine transferase, which has been

\footnotetext{
* Submitted for publication March 16, 1965; accepted June 25, 1965.

This work was supported by U. S. Public Health Service grants HE-07780 and HE-7061 and American Heart Association grant 64-G116.

$\dagger$ Address requests for reprints to Dr. Benjamin Wittels, Dept. of Pathology, Duke University Medical Center, Durham, N. C.
}

identified in both the extra- and intramitochondrial compartments of the cell.

In this paper, evidence is presented that indicates that the newborn heart, when compared with the adult heart, has a lesser capacity to oxidize long chain fatty acids, but a much greater capacity to oxidize glucose. Data obtained on examining the component parts of the long chain fatty acid oxidation pathway suggest that the inability of the newborn heart to utilize long chain fatty acids is related to low levels of long chain fatty acyl CoAcarnitine transferase activity and low concentrations of carnitine.

\section{Methods}

Spontaneously delivered, full-term rats obtained within 24 hours after birth and male rats approximately 3 months old and weighing from 225 to $275 \mathrm{~g}$ were used. All the rats were of the Osborn-Mendel strain, which has been propagated at the Duke University Medical Center for 20 years. The newborn rats remained with their mother and were allowed to nurse until used. The rats raised to adulthood were weaned at 21 days and then fed Purina laboratory chow and water ad libitum.

In assays of enzymatic activity, hearts obtained from a litter of 9 to 11 newborn rats were pooled and tested simultaneously with the heart of an adult rat. For all other determinations, several litters of newborn animals were compared with a group of adults. The hearts were used immediately after the animals were killed by a blow on the head. The tissue was blotted free of blood, weighed, homogenized in calcium-free Krebs-Ringer phosphate solution, $\mathrm{pH} 7.4$, using a conical ground glass homogenizer, and then filtered through a double layer of cheese cloth. All operations were carried out at 2 to $4^{\circ} \mathrm{C}$.

The capacity of the cardiac homogenates to oxidize selected substrates was assessed by collection of $\mathrm{C}^{14} \mathrm{O}_{2}$ from $\mathrm{C}^{14}$-labeled substrate as previously described (11). The specific activities of the palmitate and the glucose in the reaction mixtures were estimated as follows: the concentration of free fatty acid in the myocardium was determined by the method of Amenta (12), and that of glucose by the procedure of Huggett and Nixon (13). The newborn myocardium contained $0.61 \pm .08 \mu$ mole of free fatty acid per $g$ wet $w t$, and the adult, $0.49 \pm .08$. The values for glucose were $0.17 \pm 0.04 \mu$ mole per $g$ wet wt and $0.21 \pm 0.03$, respectively. The homogenates were pre- 
pared so that the wet tissue wt per volume of homogenizing medium was approximately equal for the newborn and adult hearts. Since identical amounts of radioactive fatty acid or of glucose were added to the reaction mixtures, the specific activities of the respective substrates in the reaction mixtures at the beginning of the incubation period were considered equal. To determine whether or not the specific activity changed during the incubation period, time course experiments were done over an interval of 5 to 30 minutes. During incubation, the reaction rates were linear, with a fixed ratio of $\mathrm{C}^{14} \mathrm{O}_{2}$ that was evolved maintained between newborn and adult animals. This was considered to indicate that significant net lipolysis or glycogenolysis with dilution of the free fatty acid or glucose pools did not occur during the incubation period.

After the $\mathrm{C}^{14} \mathrm{O}_{2}$ produced in the palmitate assay had been collected, the lipids in the reaction mixture were extracted as previously described (14). The dried lipid extracts were dissolved in $1 \mathrm{ml}$ of absolute ethanol. Glycerides, phospholipids, and palmitylcarnitine were separated from the extracted lipids by thin-layer silica gel chromatography. A solvent system consisting of $n$-hexane: diethyl ether: glacial acetic acid $(85: 15: 1)$ was used to separate triglycerides; lecithin and palmitylcarnitine were separated by a two dimensional system as described (15). The chromatograms were stained by exposure to iodine vapor, and the areas corresponding to the desired lipid fractions were encircled. After the iodine stained spots had completely faded, the plates were sprayed with Nea-

TABLE I

Palmitic acid-1-C $C^{14}$ oxidation by newborn and adult myocardium*

\begin{tabular}{|c|c|c|c|}
\hline \multirow{2}{*}{$\begin{array}{c}\text { Experiment } \\
\text { no. }\end{array}$} & \multicolumn{3}{|c|}{$\mathrm{C}^{14} \mathrm{O}_{2}$} \\
\hline & Newborn & Adult & Difference \\
\hline & \multicolumn{3}{|c|}{$\mu m o l e s / g$ protein $/ 15$ minutes } \\
\hline 1 & 0.40 & 1.47 & 1.07 \\
\hline 2 & 0.35 & 2.58 & 2.23 \\
\hline 3 & 0.31 & 1.62 & 1.31 \\
\hline 4 & 0.41 & 3.70 & 3.29 \\
\hline 5 & 0.66 & 4.57 & 3.91 \\
\hline 6 & 0.51 & 3.24 & 2.73 \\
\hline 7 & 0.46 & 2.72 & 2.26 \\
\hline 8 & 0.24 & 4.05 & 3.81 \\
\hline 9 & 0.42 & 3.22 & 2.80 \\
\hline 10 & 0.32 & 2.95 & 2.63 \\
\hline 11 & 0.45 & 3.59 & 3.14 \\
\hline 12 & 0.44 & 3.49 & 3.05 \\
\hline 13 & 0.48 & 1.47 & 0.99 \\
\hline 14 & 0.49 & 2.62 & 2.13 \\
\hline 15 & 0.38 & 3.41 & 3.03 \\
\hline 16 & 0.75 & 4.15 & 3.40 \\
\hline 17 & 0.88 & 3.10 & 2.22 \\
\hline Mean & 0.47 & 3.06 & 2.59 \\
\hline SE & 0.04 & 0.22 & 0.21 \\
\hline$p$ & & & $<0.01$ \\
\hline
\end{tabular}

* Each reaction flask contained palmitic acid-1-C ${ }^{14}, 100$ $\mathrm{m} \mu$ moles $(120,000 \mathrm{cpm})$, and 5 to $9 \mathrm{mg}$ of rat heart homogenate protein in $1 \mathrm{ml}$ of calcium-free Krebs-Ringer phosphate buffer, $\mathrm{pH}$ 7.4. Final reaction volume was $1.02 \mathrm{ml}$ Incubations were at $30^{\circ} \mathrm{C}$ for 15 minutes.
TABLE II

Activities of long chain fatty acid activating enzyme* and of long chain acyl CoA-carnitine transferase in newborn $^{-}$ and adult hearts

\begin{tabular}{|c|c|c|c|c|}
\hline \multirow[b]{2}{*}{ Enzyme } & \multirow{2}{*}{$\begin{array}{l}\text { No. of } \\
\text { experi- } \\
\text { ments }\end{array}$} & \multicolumn{2}{|c|}{ Palmitohydroxamate } & \multirow[b]{2}{*}{$\mathrm{p}$} \\
\hline & & Newborn & Adult & \\
\hline & \multicolumn{4}{|c|}{$\mu m o l e s / m g$ protein/60 minutes } \\
\hline LCFAAE* & 6 & $0.077 \pm 0.012 \ddagger$ & $0.283 \pm 0.011$ & $<0.01$ \\
\hline \multicolumn{5}{|c|}{ $\mu m o l e s / m g$ protein $/ 30$ minutes } \\
\hline LCCAT† & 3 & $0.023 \pm .003$ & $0.048 \pm .002$ & $<0.01$ \\
\hline
\end{tabular}

* Each reaction mixture contained palmitic acid, $4 \mu$ moles; ATP, 10 $\mu$ moles; coenzyme A (88\% pure), $1 \mu$ mole; $\mathrm{MgCl}_{2}, 15 \mu$ moles; neutralized hydroxylamine, 1 mmole; NaF, $50 \mu$ moles; cysteine, $30 \mu$ moles;

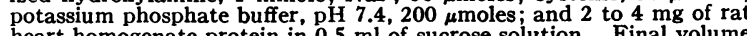
heart homogenate protein in $0.5 \mathrm{ml}$ of sucrose solution. Final volume of incubation mixture was $2.0 \mathrm{ml}$. The control incubation lacked palmitic acid. Incubations were at $40^{\circ} \mathrm{C}$ for 60 minutes.

$\dagger$ Each reaction mixture contained DL-palmitylcarnitine, $4 \mu$ moles; coenzyme A (88\% pure), 1 mole; neutralized hydroxylamine, 1 mmole; cysteine, $30 \mu$ moles; potassium phosphate buffer, $\mathrm{pH} 7.4,200$ $\mu$ moles; and 2 to $4 \mathrm{mg}$ of rat heart homogenate protein in $0.5 \mathrm{ml}$ of sucrose solution. Final volume of incubation mixture was $2.0 \mathrm{ml}$. The control incubation lacked coenzyme A. Incubations were at $40^{\circ} \mathrm{C}$ for 30 minutes.

$\ddagger$ Mean \pm standard error.

$\tan$, and the encircled areas of silica gel were transferred to vials for scintillation counting. Ten $\mathrm{ml}$ of toluene containing 2,5-diphenyloxazole (PPO, 4 g per L), 1,4 bis-2(5-phenyloxazoly1) benzene (POPOP, $100 \mathrm{mg}$ per L), and $4 \%$ Cabosil thixotropic gel powder were used as the phosphor solution.

Activity of the long chain fatty acid activating enzyme was assayed by the method of Kornberg and Pricer (16) and the activity of the long chain fatty acyl CoAcarnitine transferase by the method of Fritz and Yue (17). For these determinations, homogenates were prepared in $0.37 \mathrm{M}$ sucrose and centrifuged at 2,000 rpm at 2 to $4^{\circ} \mathrm{C}$ for 10 minutes. Portions of the resulting supernatant were used.

Carnitine concentration in the myocardium was determined enzymatically by the method of Marquis and Fritz (7).

Protein concentration was measured by the biuret method as previously described (11).

Radioactive substrates-carboxyl-labeled palmitic and hexanoic acids, ${ }^{1}$ succinate- $2,3,-C^{14}, 1$ and glucose-U-C $C^{14}{ }_{2}$ were obtained commercially. Palmitylcarnitine was prepared by the method of Fritz (17), palmityl CoA by the method of Goldman and Vagelos (18), and acetyl CoA by the method of Wieland and Koppe (19). Nonradioactive palmitic and hexanoic acids, ${ }^{3}$ DL-carnitine, ${ }^{4}$ coenzyme A,4 and ATP 5 were purchased. As determined by gas liquid chromatography, the radioactive palmitate was

1 International Chemical and Nuclear Corp., City of Industry, Calif.

2 New England Nuclear Corp., Boston, Mass.

${ }^{3}$ Applied Science Laboratories, Pennsylvania State University, University Park, Pa.

4 California Corp. for Biochemical Research, Los Angeles, Calif.

s Sigma Chemical Co., St. Louis, Mo. 
$95 \%$ chemically pure and $98 \%$ radio pure. The unlabeled palmitate was over $98 \%$ pure.

The statistical significance of the data was evaluated by applying the $t$ test to the mean differences between paired newborn litters and adults, or between groups of newborn litters and adults (20).

\section{Results}

Palmitic acid oxidation. Cardiac homogenates from newborn rats oxidized palmitate at a mean rate that was less than $20 \%$ of that shown by adult rats (Table I).

Long chain fatty acid activation. Before oxidation, long chain fatty acids are converted to long chain fatty acyl CoA by the long chain acylthiokinase in the presence of ATP and CoA (16). To ascertain whether or not the lower rate of palmitate oxidation by the newborn heart might be related to a lower rate of activation, the activity of the myocardial long chain acylthiokinase was assayed in newborn and adult rats. As shown in Table II, the activity in the newborn was less than half of that in the adult.

Addition of ATP or CoA in final concentration of from $10^{-2}$ to $10^{-4}$ mole per $\mathrm{L}$ to the oxidation assay containing palmitate failed to increase the rate of oxidation in either the newborn or adult heart.

Palmityl CoA oxidation. To circumvent the activation step in assaying long chain fatty acid oxidation, palmityl CoA was substituted for palmitic
TABLE III

\begin{tabular}{|c|c|c|c|}
\hline \multirow{2}{*}{$\begin{array}{c}\text { Experiment } \\
\text { no. }\end{array}$} & \multicolumn{3}{|c|}{$\mathrm{C}^{14} \mathrm{O}_{2}$} \\
\hline & Newborn & Adult & Difference \\
\hline & \multicolumn{3}{|c|}{$\mu m o l e s / g$ protein $/ 15$ minutes } \\
\hline $\begin{array}{l}1 \\
2 \\
3\end{array}$ & $\begin{array}{l}0.32 \\
0.21 \\
0.38\end{array}$ & $\begin{array}{l}4.11 \\
4.90 \\
4.52\end{array}$ & $\begin{array}{l}3.79 \\
4.69 \\
4.14\end{array}$ \\
\hline $\begin{array}{l}\text { Mean } \\
\text { SE } \\
\text { p }\end{array}$ & $\begin{array}{l}0.30 \\
0.05\end{array}$ & $\begin{array}{l}4.50 \\
0.23\end{array}$ & $\begin{array}{r}4.21 \\
0.26 \\
<0.01\end{array}$ \\
\hline
\end{tabular}

* Each reaction flask contained palmityl CoA-1-C ${ }^{14}, 100$ $\mathrm{m} \mu$ moles $(60,000 \mathrm{cpm})$, and 5 to $9 \mathrm{mg}$ of rat heart homogenate protein in $1 \mathrm{ml}$ of calcium-free Krebs-Ringer phosphate buffer, $\mathrm{pH}$ 7.4. Final reaction volume was $1.02 \mathrm{ml}$. Incubations were at $30^{\circ} \mathrm{C}$ for 15 minutes.

acid in the oxidation asay. Despite this, the rate of oxidation of long chain fatty acyl groups by the newborn myocardium was only a small fraction of that exhibited by the adult heart (Table III).

Long chain fatty acyl CoA-carnitine transferase and carnitine. After the formation of palmityl $\mathrm{CoA}$ in the oxidation of palmitic acid, a reaction between palmityl $\mathrm{CoA}$ and carnitine occurs whereby palmitylcarnitine is formed (17). This reaction is catalyzed by a long chain fatty acyl CoA-carnitine transferase. As shown in Table II, the activity of the long chain fatty acyl CoAcarnitine transferase in the newborn heart was only $50 \%$ of that in the adult heart.

TABLE IV

Effect of DL-carnitine on rate of oxidation of palmitic acid-1-C $C^{14}$ by newborn and adult rat hearts*

\begin{tabular}{|c|c|c|c|c|c|c|c|c|}
\hline \multirow[b]{3}{*}{ Exp. no. } & \multicolumn{7}{|c|}{$\mathrm{C}^{4} \mathrm{O}_{2}$} & \\
\hline & \multicolumn{2}{|c|}{ Newborn } & \multicolumn{2}{|c|}{ Adult } & \multicolumn{4}{|c|}{ Differences } \\
\hline & 1 & $+\underset{2}{+ \text { Carn. }} \dagger$ & 3 & $+\underset{4}{+ \text { Carn. }}$ & 3-1 & $2-1$ & $4-3$ & $3-2$ \\
\hline \multicolumn{9}{|c|}{ umoles $/ \mathrm{g}$ protein $/ 15$ minutes } \\
\hline $\begin{array}{l}1 \\
2 \\
3 \\
4 \\
5 \\
6\end{array}$ & $\begin{array}{l}0.40 \\
0.35 \\
0.66 \\
0.51 \\
0.46 \\
0.88\end{array}$ & $\begin{array}{l}1.23 \\
1.26 \\
1.82 \\
1.65 \\
1.49 \\
1.81\end{array}$ & $\begin{array}{l}1.47 \\
2.58 \\
4.57 \\
3.24 \\
2.72 \\
3.10\end{array}$ & $\begin{array}{l}2.03 \\
2.94 \\
4.80 \\
3.95 \\
2.87 \\
3.56\end{array}$ & $\begin{array}{l}1.07 \\
2.23 \\
3.91 \\
2.73 \\
2.26 \\
2.22\end{array}$ & $\begin{array}{l}0.83 \\
0.91 \\
1.16 \\
1.14 \\
1.03 \\
0.93\end{array}$ & $\begin{array}{l}0.56 \\
0.36 \\
0.23 \\
0.71 \\
0.15 \\
0.46\end{array}$ & $\begin{array}{l}0.24 \\
1.32 \\
2.75 \\
1.59 \\
1.23 \\
1.29\end{array}$ \\
\hline $\begin{array}{l}\text { Mean } \\
\text { SE } \\
\mathrm{p}\end{array}$ & $\begin{array}{l}0.54 \\
0.08\end{array}$ & $\begin{array}{l}1.54 \\
0.11\end{array}$ & $\begin{array}{l}2.95 \\
0.41\end{array}$ & $\begin{array}{l}3.36 \\
0.39\end{array}$ & $\begin{array}{r}2.40 \\
0.38 \\
<0.01\end{array}$ & $\begin{array}{r}1.00 \\
0.54 \\
<0.01\end{array}$ & $\begin{array}{r}0.41 \\
0.09 \\
<0.01\end{array}$ & $\begin{array}{r}1.40 \\
0.33 \\
<0.01\end{array}$ \\
\hline
\end{tabular}

${ }^{*}$ Each reaction flask contained palmitic acid-1-C ${ }^{14}, 100 \mathrm{~m} \mu$ moles $(120,000 \mathrm{cpm})$, and 5 to $9 \mathrm{mg}$ of rat heart homogenate protein in $1 \mathrm{ml}$ of calcium-free Krebs-Ringer phosphate solution, $\mathrm{pH} 7.4$. DL-Carnitine, $10^{-3} \mathrm{mmole}$, was added where indicated. Final reaction volume was $1.03 \mathrm{ml}$. Incubations were at $30^{\circ} \mathrm{C}$ for 15 minutes. $\dagger$ DL-Carnitine. 
TABLE V

Incorporation of palmitate-1-C $C^{14}$ into lipid fractions of newborn and adult hearts*

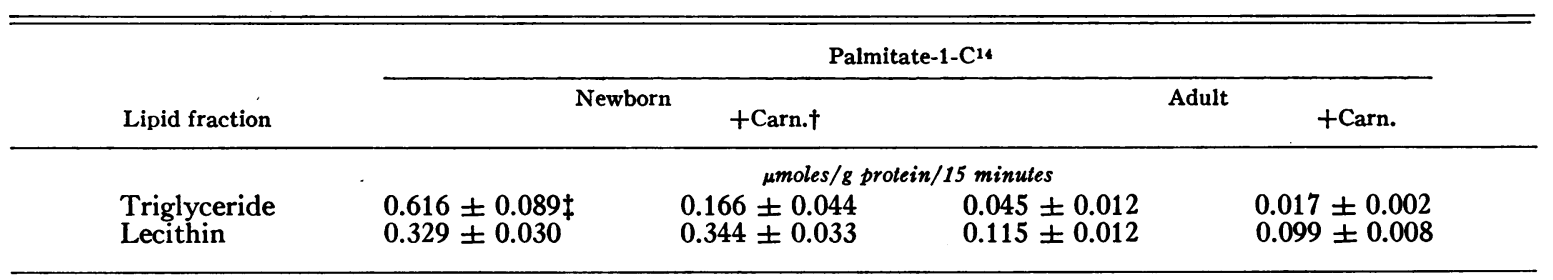

* Each reaction flask contained palmitic acid-1-C ${ }^{14}, 100 \mathrm{~m} \mu$ moles $(120,000 \mathrm{cpm})$, and 5 to $9 \mathrm{mg}$ of rat heart homogenate protein in $1 \mathrm{ml}$ of calcium-free Krebs-Ringer phosphate solution, $\mathrm{pH} \mathrm{7.4.} \mathrm{DL-Carnitine,} 10^{-3} \mathrm{mmole}$, was added where indicated. Final reaction volume was $1.03 \mathrm{ml}$. Incubations were at $30^{\circ} \mathrm{C}$ for 15 minutes. Extraction and separation of lipids were then carried out as described under Methods. Six experiments were done without the addition of carnitine; in three of the experiments carnitine was added to companion incubation flasks.

$\dagger$ DL-Carnitine.

$\ddagger$ Mean \pm standard error.

Quantification of myocardial carnitine revealed that its mean concentration in the newborn was approximately $25 \%$ of that in the adult. In a group of six litters of newborn rats, the carnitine levels ranged from 0.25 to $0.49 \mu$ mole per $g$ wet wt (mean $=0.39 ; \mathrm{SE}=0.04$ ), whereas in a group of six adult rats the levels ranged from 1.41 to 1.85 (mean $=1.66 ; \mathrm{SE}=0.07$ ). The difference is statistically significant $(p<0.01)$.

Addition of DL-carnitine in a final concentration of $10^{-3}$ mole per $\mathrm{L}$ to reaction mixtures containing palmitate increased the oxidation of this substrate threefold in the newborn and only $15 \%$ in the adult (Table IV). Despite the increase effected by exogenous carnitine in the newborn, the level achieved was only approximately half of that shown by the reaction mixture of the adult, to which carnitine was not added.

TABLE VI

Incorporation of palmitate-1-C $C^{14}$ into palmitylcarnitine of newborn and adult hearts*

\begin{tabular}{|c|c|c|c|}
\hline \multirow{2}{*}{$\begin{array}{l}\text { Experiment } \\
\text { no. }\end{array}$} & \multicolumn{3}{|c|}{ C14-Palmitylcarnitine } \\
\hline & Newborn & Adult & Difference \\
\hline & \multicolumn{3}{|c|}{ umoles $/ \mathrm{g}$ protein $/ 15$ minutes } \\
\hline $\begin{array}{l}1 \\
2 \\
3\end{array}$ & $\begin{array}{l}0.023 \\
0.042 \\
0.019\end{array}$ & $\begin{array}{l}0.156 \\
0.122 \\
0.084\end{array}$ & $\begin{array}{l}0.133 \\
0.080 \\
0.065\end{array}$ \\
\hline $\begin{array}{l}\text { Mean } \\
\text { SE } \\
\text { p }\end{array}$ & $\begin{array}{l}0.028 \\
0.007\end{array}$ & $\begin{array}{l}0.121 \\
0.021\end{array}$ & $\begin{array}{r}0.093 \\
0.021 \\
<0.025\end{array}$ \\
\hline
\end{tabular}

* Each reaction flask contained palmitic acid-1-C14, 100 $\mathrm{m} \mu$ moles $(120,000 \mathrm{cpm})$, palmitylcarnitine, $2 \mu \mathrm{moles}$, and 6 to $7 \mathrm{mg}$ of rat heart homogenate protein in $1 \mathrm{ml}$ calciumfree Krebs-Ringer phosphate buffer, $\mathrm{pH}$ 7.4. Final reaction volume was $1.11 \mathrm{ml}$. Incubations were at $30^{\circ} \mathrm{C}$ for $15 \mathrm{~min}$ utes. Extraction and separation of palmitylcarnitine were carried out as described under Methods.
Incorporation of palmitate-1-C $C^{\mathbf{1 4}}$ into triglyceride, lecithin, and palmitylcarnitine. The steady state levels of incorporation of radioactive palmitate into both triglyceride and lecithin by the newborn heart were higher than those shown by the adult (Table V). In the newborn, esterification of palmitate even exceeded oxidation (Tables I and $\mathrm{V}$ ). Whereas the steady state level of triglyceride formation was greater than lecithin in the newborn, the opposite occurred in the adult ( Table V).

In the presence of exogenous carnitine, the palmitate incorporation into triglycerides was markedly decreased in the newborn but only slightly decreased in the adult. On the other hand, carnitine had no effect on the rate of palmitate incorporation into lecithin in either newborn or adult.

As shown in Table VI, the steady state level of palmitylcarnitine was lower in the newborn heart than in the adult. The ratio between these levels approximates the ratio between the rates of palmitate oxidation in the newborn and adult (Table I).

Hexanoic acid and succinic acid oxidation. The newborn heart oxidized hexanoate-1- $\mathrm{C}^{14}$ at a rate equivalent to that of the adult and succinate-2, $3-\mathrm{C}^{14}$ at a rate greater than that of the adult ( $\mathrm{Ta}-$ ble VII). These data indicate that $\beta$-oxidation and the activities of the Krebs cycle and the electron transport chain in the newborn heart were not less than in the adult heart.

Glucose oxidation. As also shown in Table VII, the rate of oxidation of glucose-U-C $\mathrm{C}^{14}$ was approximately ten times greater in the newborn than in the adult heart. 
TABLE VII

Oxidation of various substrates by newborn and adult hearts*

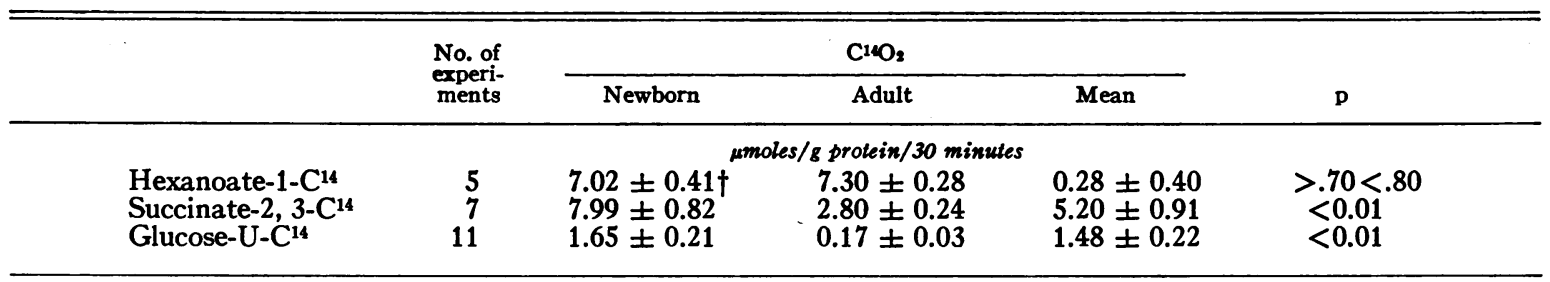

* Each reaction flask contained 5 to $9 \mathrm{mg}$ of rat heart homogenate protein in $1 \mathrm{ml}$ of calcium-free Krebs-Ringer phosphate solution, $\mathrm{pH} 7.4$, and hexanoic acid-1-C $14,1 \mu$ mole $(150,000 \mathrm{cpm})$, succinic acid-2, $3-\mathrm{C}^{14}, 1 \mu \mathrm{mole}(250,000 \mathrm{cpm})$, or glucose-U-C ${ }^{4,}, 1 \mu$ mole $(400,000 \mathrm{cpm})$. Final reaction volume was $1.02 \mathrm{ml}$. Incubations were at $30^{\circ} \mathrm{C}$ for $30 \mathrm{minutes}$. $\dagger$ Mean \pm standard error.

\section{Discussion}

Long chain fatty acid metabolism in the newborn rat heart as compared with the adult rat heart was characterized by 1 ) a lower rate of oxidation of palmitic acid and palmityl CoA, 2) a lower activity of long chain fatty acylthiokinase, 3 ) a lower activity of long chain fatty acyl CoA-carnitine transferase, 4) a lower concentration of carnitine, and 5) a higher steady state rate of incorporation of palmitic acid into triglyceride and into lecithin.

Long chain fatty acid oxidation. In the initial step of long chain fatty acid oxidation, the long chain fatty acylthiokinase catalyzes the conversion of palmitic acid to palmityl $\mathrm{CoA}$ in the presence of CoA and ATP (16). Since the activity of the thiokinase was significantly lower in the newborn heart than in the adult heart, a diminished rate of long chain fatty acid activation could have been responsible for the lower rate of palmitate oxidation in the newborn. Like oxidation, however, incorporation of palmitate into glycerides and phospholipids also requires activation of the fatty acids (21). In the newborn, the combined steady state rates of incorporation of palmitate into triglycerides and lecithin were twofold greater than that of palmitate oxidation. This indicates that palmitic acid activation could not have been rate limiting in the oxidation of long chain fatty acid by the newborn heart. This is supported by the demonstration that when the activation step was circumvented by utilizing palmityl $\mathrm{CoA}$ as substrate, the oxidation rate of long chain acyl groups by the newborn heart was still very limited as compared with the adult heart.

In the next step of long chain fatty acid oxidation, the activated acyl groups react with carnitine to form acylcarnitine esters (17). As such, the long chain fatty acids appear to be translocated into the mitochondria $(9,10)$. The activity of the long chain fatty acyl CoA-carnitine transferase, the concentration of carnitine, and the rate of palmitylcarnitine formation in the newborn rat heart were significantly lower than in the adult. Singly or in combination, lack of the transferase activity or of carnitine could have acounted for the diminished rate of palmitic acid oxidation in the newborn. By addition of carnitine to the oxidation assay of the newborn the rate of oxidation was increased threefold, but the level achieved was still only $50 \%$ of that shown by the adult reaction mixture to which carnitine was not added. Under these in vitro conditions in which carnitine was present in excess, and in which $\beta$-oxidation and the activities of the Krebs cycle and the electron transport chain were not lower than they were in the adult, the activity of the long chain fatty acyl CoA-carnitine transferase appeared to be a rate limiting factor in palmitic acid oxidation in the newborn heart. In vivo, however, the low carnitine concentration may be equal in significance to or more significant than the low transferase activity in limiting the oxidation rate of long chain fatty acids in the newborn heart. Evidence has been obtained that suggests that lack of carnitine alone can limit the rate of long chain fatty acid oxidation in the heart (11). Further analysis of this problem in the newborn heart would require manipulation of the level of activity of the transferase in the assay of palmitate oxidation. This may be possible if a differential rate of increase in carnitine concentration and transferase activity in the heart can be demonstrated during growth and development of the newborn rat. 
Long chain fatty acid esterification. In contrast to palmitate oxidation in which the rate in the adult exceeded that in the newborn, the steady state rate of palmitate incorporation into triglycerides was greater in the newborn. On the addition of carnitine to the reaction mixture, palmitate conversion to triglyceride decreased. Thus, in the presence of exogenous carnitine there was both an increased palmitate oxidation and a decreased palmitate conversion to triglyceride. Both of these effects were far more notable in the newborn heart in which the endogenous carnitine levels were lower. The pronounced redistribution of palmitate between $\mathrm{CO}_{2}$ evolved and triglyceride formed after the addition of carnitine to the newborn heart may indicate that the palmitate converted to triglyceride when the concentration of carnitine is suboptimal may be redirected to oxidation when the carnitine concentration is raised. Such a relationship between $\mathrm{CO}_{2}$ evolved, triglyceride formed, and carnitine concentration is evident not only in the newborn heart in the presence and absence of exogenous carnitine but also in the newborn and adult hearts when carnitine has not been added. Since carnitine has no direct effect on the conversion of long chain fatty acids to glyceride $(14,22)$, the fluctuations in the rate of triglyceride formation related to carnitine concentration appear to be secondary to the concurrent rate of long chain fatty acid oxidation. Fritz arrived at the same conclusion on investigating the effect of carnitine on palmitate oxidation and glyceride formation in the hearts and livers of adult rats (22).

The steady state rate of palmitate incorporation into lecithin was also higher in the newborn than in the adult heart, but, in contrast to triglycerides and $\mathrm{CO}_{2}$, its formation was not affected by exogenous carnitine. Friedberg and Bressler also noted the failure of carnitine to influence the rate of palmitate incorporation into lecithin (23). Under the conditions used by these investigators carnitine did, however, have an effect on incorporation of palmitate-1-C $\mathrm{C}^{14}$ into palmitylcarnitine. The lower concentration of endogenous carnitine and the lower steady state level of palmitylcarnitine in the newborn heart as compared with the adult heart are in accord with the previous investigations.

Glucose oxidation. Since the classical investigations of Needham on the metabolism of the de- veloping chick embryo (24), considerable evidence has accumulated that suggests that carbohydrates are the major source of energy for immature organs $(4,5)$. That this obtains in the heart is supported by the presence of higher levels of cardiac glycogen during fetal and neonatal growth than in adult life $(25,26)$, and higher rates of activity in the newborn heart of some enzymes involved in carbohydrate metabolism (27). The observations that the newborn rat heart lacked the capacity to oxidize long chain fatty acid at the rate achieved by the adult heart, but greatly exceeded the adult in the ability to oxidize glucose, are consonant with the proposal that carbohydrates may be the major substrate for energy production in the newborn heart.

Dietary factor. The marked differences in cardiac metabolism observed between the newborn and adult rat might have been related to dietary differences rather than to the differences in age and degree of maturation. Rat colostrum contains approximately $22 \%$ fat and $3 \%$ carbohydrate (28), whereas the laboratory chow used for the adult rats contained approximately $4 \%$ fat and $50 \%$ carbohydrate. If the levels of dietary fat and carbohydrate reflect the concentrations of free fatty acid and glucose presented to the heart in vivo, and the oxidative capacity of the myocardium is proportional to substrate availability, a greater capacity for long chain fatty acid oxidation and a lesser capacity for glucose oxidation in the newborn heart as compared with the adult might have been expected. The opposite, however, was observed.

It has been demonstrated that the level of plasma free fatty acid in the fetal lamb is very low as compared with the sheep, that immediately after birth the levels are low in man and the lamb, and that during the early postnatal period the levels rise rapidly to attain those present in the adult (29). Since the capacity of the heart of the nursing infant rat to oxidize palmitic acid increases to approximately $50 \%$ of the adult rate by 5 days of age and is not significantly different from the adult by 10 days after birth (30), an induction period during which plasma free fatty acid levels are higher than they are during fetal life may be necessary for the infant heart to increase its capacity for long chain fatty acid oxidation. Such an adaptive phase 
has been observed in the fasting adult guinea pig in which there is a 4- to 5-day interval between the marked elevation of the plasma free fatty acid concentration and the increased capacity of the heart to oxidize long chain fatty acids (31).

\section{Summary}

The newborn heart, when compared with the adult heart, possesses a limited capacity to oxidize long chain fatty acids. Analysis of the component parts of the long chain fatty acid oxidation pathway suggests that this limitation is related to a low level of long chain fatty acyl CoA-carnitine transferase activity and a low concentration of its cofactor, carnitine. According to the current hypothesis concerning the metabolic function of this enzyme and its cofactor, these deficits might impede long chain fatty acid oxidation in the newborn heart by limiting the rate of transfer of activated long chain fatty acyl groups to the mitochondrial sites of long chain fatty acid oxidation. As a consequence, the newborn heart, having a greater capacity than the adult to oxidize glucose, may be forced to rely upon carbohydrates as a primary source of energy.

Age and dietary differences as related to the differences in cardiac metabolism between the newborn and adult rat are also discussed.

\section{References}

1. Shipp, J. C. Interrelation between carbohydrate and fatty acid metabolism of isolated perfused rat heart. Metabolism 1964, 13, 852.

2. Carlsten, A., B. Hallgren, R. Jagenburg, A. Svanborg, and L. Werkö. Myocardial metabolism of glucose, lactic acid, amino acids and fatty acids in healthy human individuals at rest and at different work loads. Scand. J. clin. Lab. Invest. 1961, 13, 418.

3. Evans, J. R. Importance of fatty acid in myocardial metabolism in Structure and Function of Heart Muscle, J. R. Evans, Ed. American Heart Association Monograph, 1964, vol. 9, p. 96.

4. Popjak, G. The origin of fetal lipids in The Mammalian Fetus: Physiological Aspects of Development. Cold Spring Harbor Symposia on Quantitative Biology, 1954, vol. 19, p. 200.

5. Villee, C. A., and D. D. Hagerman. Effects of oxygen deprivation on the metabolism of fetal and adult tissues. Amer. J. Physiol. 1958, 194, 457.
6. Fritz, I. The effects of muscle extracts on the oxidation of palmitic acid by liver slices and homogenates. Acta physiol. scand. 1955, 34, 367.

7. Marquis, N. R., and I. B. Fritz. Enzymological determination of free carnitine concentrations in rat tissues. J. Lipid Res. 1964, 5, 184.

8. Fraenkel, G. S., and S. Friedman. Carnitine in Vitamins and Hormones, R. S. Harris, G. F. Marrian, and K. V. Thimann, Eds. New York, Academic Press, 1957, p. 73.

9. Fritz, I. B. Carnitine and its role in fatty acid metabolism in Advances in Lipid Research, R. Paoletti and D. Kritchensky, Eds. New York, Academic Press, 1963, vol. 1, p. 285.

10. Bressler, R., R. Katz, and B. Wittels. The role of carnitine in the intracellular translocation of acyl coenzyme A derivatives. Ann. N. Y. Acad. Sci. In press.

11. Wittels, B., and R. Bressler. Biochemical lesion of diphtheria toxin in the heart. J. clin. Invest. 1964, 43, 630.

12. Amenta, J. S. A rapid chemical method for quantification of lipids separated by thin-layer chromatography. J. Lipid Res. 1964, 5, 270.

13. Huggett, A. St G., and D. A. Nixon. Enzymatic determination of blood glucose (abstract). Biochem. J. 1957, 66, 12p.

14. Bressler, R., and S. J. Friedberg. The effect of carnitine on the rate of palmitate incorporation into mitochondrial phospholipids. J. biol. Chem. 1964, 239, 1364.

15. Wittels, B., and R. Bressler. Two-dimensional thinlayer chromatographic isolation of fatty acyl carnitines. J. Lipid Res. 1965, 6, 313.

16. Kornberg, A., and W. E. Pricer, Jr. Enzymatic synthesis of the co-enzyme A derivatives of long chain fatty acids. J. biol. Chem. 1953, 204, 329.

17. Fritz, I. B., and K. T. N. Yue. Long-chain carnitine acyltransferase and the role of acylcarnitine derivatives in the catalytic increase of fatty acid oxidation induced by carnitine. J. Lipid Res. 1963, 4, 279.

18. Goldman, P., and P. R. Vagelos. The specificity of triglyceride synthesis from diglycerides in chicken adipose tissue. J. biol. Chem. 1961, 236, 2620.

19. Stadtman, E. R. Preparation and assay of acyl coenzyme $A$ and other thiol esters in Methods in Enzymology, S. P. Colowick and N. O. Kaplan, Eds. New York, Academic Press, 1957, vol. 3, p. 931.

20. Dixon, W. J., and F. J. Massey, Jr. Introduction to Statistical Analysis, 2nd ed. New York, McGrawHill, 1957, p. 119.

21. Kornberg, A., and W. E. Pricer, Jr. Enzymatic esterification of $\alpha$-glycerophosphate by long chain fatty acids. J. biol. Chem. 1953, 204, 345.

22. Fritz, I. B. Carnitine effects on palmitate-1-C $\mathrm{C}^{14}$ conversion to $\mathrm{CO}_{2}$ and glycerides by various tissues. Amer. J. Physiol. 1964, 206, 1217.

23. Friedberg, S. J., and R. Bressler. The formation and isolation of long chain acyl carnitines in mito- 
chondria. Biochim. biophys. Acta (Amst.) 1965, 98, 335.

24. Needham, J. Biochemistry and Morphogenesis. Cambridge, Cambridge University Press, 1942.

25. Shelley, H. J. Glycogen reserves and their changes at birth and in anoxia. Brit. med. Bull. 1961, 17, 137.

26. Wittels, B. Myocardial glycogen in the fetus, infant, and child. Arch. Path. 1963, 75, 127.

27. Stave, V. Age-dependent changes in metabolism. I. Studies of enzyme patterns of rabbit organs. Biol. Neonat. (Basel) 1964, 6, 128.
28. Luckey, T. D., T. V. Mende, and V. Pleasants. The physical and chemical characterization of rat's milk. J. Nutr. 1954, 54, 345.

29. Van Duyne, C. M., and R. J. Havel. Plasma unesterified fatty acid concentration in fetal and neonatal life. Proc. Soc. exp. Biol. (N. Y.) 1959, 102, 599.

30. Wittels, B., and R. Bressler. Unpublished observations.

31. Wittels, B., and R. Bressler. Lipid metabolism in the heart during fasting. Lab. Invest. 1964, 13, 794. 